\title{
INOVASI PENGOLAHAN ABON LOKAN (Pilsbryoconcha exilis) DENGAN PERLAKUAN SUBSTITUSI TEBU TELUR (Saccharum edule)
}

\section{INNOVATION OF ABON LOKAN (Pilsbryoconcha exilis) PROCESSING USING TEBU TELUR (Saccharum edule) SUBSTITUTION}

\author{
Hesti Nur'aini' ${ }^{1)}$, Ishar ${ }^{1)}$, Darius ${ }^{1)}$ \\ 1) Program Studi Teknologi Hasil Pertanian, Fakultas Pertanian, \\ Universitas Dehasen Bengkulu \\ Email : hestinuraini@unived.a.id
}

\begin{abstract}
ABSTRAK
Abon lokan merupakan salah satu produk pangan yang terbuat dari daging yang disuwir-suwir dan ditambahkan bumbu kemudian dilakukan penggorengan dan pengepresan. Melihat harga lokan yang mahal, maka perlu dilakukan substitusi menggunakan bahan berprotein tinggi yang memiliki harga lebih ekonomis. Telah dilakukan penelitian dengan tujuan untuk mengevaluasi pengaruh substitusi tebu telur dalam pengolahan abon lokan, terhadap sifat kimia dan organoleptik abon lokan, serta menentukan komposisi bahan baku yang tepat dalam pengolahan abon lokan substitusi tebu telur.

Penelitian ini menggunakan faktor tunggal, dengan faktor perlakuan komposisi tebu telur : lokan ((0:400), (50:350), (100:300), (150:250), (200:200), dan (250:150)) gram. Analisis yang dilakukan meliputi analisis protein, analisis serat kasar, analisis usaha, dan uji sensoris untuk mengetahui tingkat penerimaan panelis terhadap abon lokan, menggunakan 20 orang panelis agak terlatih.

Hasil penelitian menunjukkan bahwa substitusi tebu telur pada pembuatan abon lokan berpengaruh terhadap kandungan protein, serat kasar dan tingkat kesukukaan panelis pada parameter warna, rasa dan tekstur abon lokan. Konsentrasi tebu telur yang tepat untuk menghasilkan abon terbaik adalah pada perlakuan $150 \mathrm{~g}$ tebu telur dan $250 \mathrm{~g}$ daging lokan, dengan nilai protein sebesar $19,107 \%$, serat kasar $0,967 \%$, tingkat kesukaan terhadap warna sebesar 3,80 (suka), rasa sebesar 4,80 (sangat suka), dan tekstur sebesar 4,70 (sangat suka). Hasil analisis usaha abon lokan substitusi tebu telur dengan komposisi 150 gr : 250 gr diperoleh keuntungan sebesar Rp 38.353/kg.
\end{abstract}

Kata Kunci: substitusi, tebu telur, abon lokan

\section{ABSTRACT}

"Abon lokan" is one of the food products made from shredded meat and added seasonings then frying and pressing. Seeing the expensive price of "lokan", it is necessary to substitute using high protein materials which have a more economical price. Research has been conducted with the aim to evaluate the effect of "tebu telur" substitution in "abon lokan" processing, on the chemical and organoleptic properties of "abon lokan", and determine the composition of materials in "abon lokan" with "tebu telur" substitute processing.

This study uses a single factor, with the factor of "tebu telur : lokan" composition ((0: 400), (50: 350), (100: 300), (150: 250), (200: 200), and (250: 150$))$ gram treatment. The 
analysis included protein analysis, crude fiber analysis, business analysis, and sensory testing to determine the level of panelist acceptance of "abon lokan", using 20 rather trained panelists.

The results showed that the substitution of "tebu telur" in the production of "anon lokan" had an effect on protein content, crude fiber and the level of panelists' preference on the colour, taste, and texture of "abon lokan". The best composition to produce the best "abon lokan" is $150 \mathrm{~g}$ of "tebu telur" and $250 \mathrm{~g}$ of "lokan", with a protein value of $19,107 \%$, crude fiber 0,967\%, a degree of preference for color of 3,80 (likes), a taste of 4, 80 (really like), and texture of 4.70 (really like). The results of the analysis of "abon lokan" with "tebu telur" substitution (150 gr: $250 \mathrm{gr}$ ) obtained a profit of $\mathrm{Rp} 38,353 / \mathrm{kg}$.

Keyword : substitution, "tebu telur”, "abon lokan”

\section{PENDAHULUAN}

Kebutuhan daging sebagai salah satu sumber protein hewani semakin meningkat. Hal ini dipengaruhi oleh bertambahnya jumlah penduduk dari tahun ke tahun yang juga diikuti oleh peningkatan kebutuhan pangan. Upaya pemenuhan kebutuhan akan daging, khusunya daging lokan atau lokan dapat dilakukan dengan cara pengembangan budidaya lokan skala rumah tangga. Tingginya tingkat konsumsi produk olahan peternakan merupakan suatu peluang usaha tersendiri untuk dikembangkan. Bergesernya pola konsumsi masyarakat dalam mengkonsumsi produk olahan peternakan, terutama daging, dari mengkonsumsi daging segar menjadi produk olahan siap santap mendorong untuk dikembangkannya teknologi dalam hal pengolahan daging. Banyak cara yang dikembangkan untuk meningkatkan nilai guna dan daya simpan dari daging segar seperti diolah menjadi sosis, dendeng dan abon (Suryani, 2005).

Seiring dengan perkembangan dunia industri dan kemajuan teknologi saat ini, lebih-lebih di era globalisasi maka sebagai manusia dituntut untuk lebih kreatif dan terampil dalam memecahkan suatu masalah yang dihadapi dengan tujuan mampu menciptakan produk yang bermanfaat dan berkualitas, khususnya bagi industri. Maka timbullah sebuah ide atau gagasan bagi seseorang untuk dapat melakukan kegiatan produksinya dengan metode yang lebih efektif dan efisien, sebagai upaya yang paling mudah dan tepat untuk merealisasikan hal itu dengan potensi bidang usaha yang dituju (Suryani, 2005). Pengolahan merupakan salah satu cara untuk memperpanjang masa simpan serta mutu dari suatu bahan pangan. Menggunakan proses pengolahan yang 
baik tentunya akan menghasilkan produk yang baik pula. Namun, dari sekian banyak jenis pengolahan, perlu diketahui pengolahan yang paling tepat untuk menghasilkan suatu produk sehingga dapat meminimalisir tingkat kehilangan atau penurunan kandungan gizi yang dikandung setelah diolah, sehingga nutrisi yang terdapat pada bahan tersebut tetap dapat dipertahankan, yang salah satunya adalah abon (Fachruddin, 2007).

Abon merupakan salah satu bentuk olahan yang umumnya dibuat dari daging yang disuwir-suwir dan ditambahkan bumbu kemudian dilakukan penggorengan dan pengepresan. (Fachruddin, 2007). Badan Standarisasi Nasional Indonesia (2005), mendefinisikan abon sebagai suatu jenis makanan kering berbentuk khas yang terbuat dari daging yang direbus, disayat-sayat, dibumbui, digoreng dan dipres dengan berbagai cara pengolahan lain. Lebih lanjut, Astawan (2008) mendefinisikan abon sebagai daging kering yang telah disayat-sayat menjadi serat-serat yang halus dan umumnya dibuat dari daging sapi. Menurut Sutrisno, (2010) semua jenis daging ternak dapat digunakan untuk membuat abon. Umumnya abon dibuat dari daging sapi, ayam atau daging ikan, hal ini dikarenakan bahan tersebut banyak tersedia di pasaran dan disukai oleh semua kalangan usia. Menurut Astawan (2008), proses pembuatan abon belum dibakukan, karena banyak cara dan bumbu yang ditambahkan sehingga terdapat variasi macam dan jumlah bumbu yang digunakan, hal ini menyebabkan kualitas abon beraneka ragam terutama dalam hal rasa dan warna. Prinsip pembuatan abon adalah perebusan daging, penyeratan, pencampuran bumbu, gula merah, garam dan penggorengan minyak sampai kering. Upaya pengembangan industri abon tidak begitu sulit karena bahan baku untuk pembuatan abon mudah didapat di setiap daerah. Pemilihan bahan baku dapat didasarkan atas ketersediaan jenis bahan baku yang terdapat di daerah tersebut dan kemudahan memperolehnya (Fachruddin, 2007), seperti halnya lokan (Pilsbryoconcha exilis) dan ikan, sebagai komoditas lokal di Provinsi Bengkulu. Leksono dan Syahrul (2001) menyatakan bahwa abon ikan yang dikemas dalam kemasan plastik mempunyai umur simpan kurang lebih 40 hari.

Lokan adalah salah satu jenis organisme air berjenis kerang-kerangan yang mempunyai bentuk tubuh bilateral atau simetri, tidak beruas-ruas, tubuh lunak dan ditutupi mantel yang menghasilkan zat kapur, bentuk kepala jelas, bernapas dengan paru-paru atau insang (Suwignyo, 2008). Dilihat dari nilai gizinya, lokan memiliki kandungan protein $(5,67-7,37 \%)$ dan vitamin $\mathrm{B} 1$ 
yang cukup tinggi, yaitu 7,37\% dan 100 $\mu \mathrm{g}$ per 100 gram (Suhardjo, 2007), sehingga berpotensi untuk menjadi sumber protein bagi masyarakat. Di wilayah Provinsi Bengkulu, lokan banyak ditemukan di wilayah pesisir utara dan menjadi salah satu makanan favorit masyarakat Bengkulu. Saat ini, variasi pengolahan lokan masih terbatas sebagai lauk segar, seperti rendang dan gulai lokan, sehingga potensi diverisifikasi produk olahan lokan masih sangat besar, salah satunya adalah pengolahan lokan menjadi abon. Abon lokan dapat dijadikan sebagai salah satu alternatif penganekaragaman produk olahan utamanya untuk bahan pangan yang bernilai ekonomi tinggi. Pembuatan abon lokan relatif mudah dan dapat dijadikan sebagai alternatif sumber pendapatan keluarga, serta dapat dilakukan dalam skala kecil maupun skala industri (Fachruddin, 2007).

Selain komoditas lokan, komoditas pangan sumber protein lain juga banyak tersedia di Provinsi Bengkulu, seperti tebu telur (Saccharum edule) yang merupakan sumber protein nabati. Tebu telur mempunyai kandungan protein sebesar 4,6\% dan banyak mengandung mineral terutama kalsium dan fosfor, disamping vitamin C. selain itu, dalam $100 \mathrm{~g}$ tebu telur segar mengandung air $89 \mathrm{~g}$, karbohidrat 6,9-7,6 $\mathrm{g}$, serat 0,7 g, Ca $10 \mathrm{mg}, \mathrm{Fe} \mathrm{0,4-2} \mathrm{mg}$, fosfor $80 \mathrm{mg}$, vitamin C $21 \mathrm{mg}$ dengan total energi sebesar 143-160 kj/100 $\mathrm{g}$ (Nangimam, 2015). Dilihat dari nilai gizinya, tebu telur sangat potensial untuk dikembangkan menjadi produk pangan lokal, yang salah satunya adalah sebagai substituen dalam pengolahan abon lokan. Selama ini, masyarakat mengkonsumsi tebu telur hanya sebagai bahan tambahan dalam pengolahan sayur santan. Substitusi tebu telur dalam pengolahan abon lokan diharapkan mampu menghasilkan produk abon berbahan baku komoditas lokal Bengkulu yang kaya protein dengan kualitas gizi dan sensoris yang tinggi. Metode pengolahan abon lokan yang disubstitusi dengan tebu telur relatif lebih sederhana dengan waktu yang lebih singkat dibandingkan dengan pengolahan abon daging atau abon ikan, sehingga bisa menurunkan biaya produksi pengolahan abon. Berdasarkan uraian di atas maka perlu dilakukan penelitian tentang karakteristik mutu abon berbahan dasar lokan dan tebu telur, serta bagaimana tingkat penerimaan konsumen. Oleh karena itu, tujuan penelitian ini adalah untuk mengevaluasi pengaruh substitusi tebu telur dalam pengolahan abon lokan terhadap sifat kimia dan organoleptik abon lokan. 


\section{METODE PENELITIAN}

Bahan yang digunakan pada
penelitian ini $\begin{gathered}\text { adalah lokan } \\ \text { (Pilsbryoconcha exilis) }\end{gathered}$ (Saccharum edule Hasskarl) yang diperoleh dari Pasar Pagar Dewa Kota Bengkulu, minyak goreng, bawang merah, bawang putih, garam, lengkuas, serai, ketumbar, kunyit, lada, santan. Bahan lokan dan tebu telur, serta bahan-bahan analisis. Alat yang digunakan dalam penelitian ini adalah alat-alat pengolahan abon seperti baskom, wajan, kompor, sendok, blender, pengepres, garpu dan pisau, serta alat-alat untuk uji laboratorium seperti oven, soxhlet, cawan porselen, tanur, lumpang, desikator, timbangan analitik, wadah plastik, panci dan pisau, gelas kimia, labu kjedahl.

Penelitian ini dilakukan dalam 2 (dua) tahap, yaitu tahap pengolahan abon lokan dan tahap analisis. Pengolahan abon lokan dan tebu telur diawali dengan penyiapan bumbu, kemudian dilanjutkan dengan penyuwiran daging lokan rebus dan penghancuran tebu telur. Selanjutnya penggorengan lokan suwir, tebu telur halus dan bumbu selama 10 menit, dengan komposisi sesuai perlakuan, yaitu perbandingan tebu telur dan lokan. Penelitian ini adalah penelitian faktor tunggal, dengan faktor perlakuan komposisi tebu telur : lokan ((0 : 400), (50
: 350), (100: 300), (150: 250), (200: 200), dan (250:150)) gram. Analisis yang dilakukan dalam penelitian ini meliputi analisis protein, analisis serat kasar (Sudarmadji, dkk, 1997), analisis usaha, serta uji sensoris untuk mengetahui tingkat penerimaan panelis terhadap abon lokan, menggunakan 20 orang panelis agak terlatih (Setyaningsih dkk, 2010)

\section{HASIL DAN PEMBAHASAN}

\section{Kadar Protein Abon Lokan Substitusi}

\section{Tebu Telur}

Protein adalah suatu bahan makanan makronutrien, mengandung unsur nitrogen yang tidak terdapat dalam karbohidrat dan lemak. Protein sangat penting bagi tubuh, karena zat ini berfungsi sebagai zat pembangun dan pengatur. Protein dalam bahan biologis biasanya terdapat dalam bentuk ikatan fisis yang renggang maupun ikatan kimiawi yang lebih erat dengan karbohidrat atau lemak (Sudarmadji dkk, 1997). Pada sebagian besar jaringan tubuh, protein merupakan komponen terbesar setelah air, diperkirakan separuh atau $50 \%$ dari berat kering sel dalam jaringan seperti misalnya hati dan daging terdiri dari protein (Syarief dan Anies, 2008). Hasil analisis kadar protein abon lokan yang disubstitusi tebu telur disajikan pada Tabel 1. 
Tabel 1. Kadar Protein Abon Lokan Substitusi Tebu Telur (\%)

\begin{tabular}{ccc}
\hline \multicolumn{2}{c}{ Perlakuan Komposisi } & Rerata \\
$\begin{array}{c}\text { Tebu Telur } \\
(\text { gr })\end{array}$ & $\begin{array}{c}\text { Daging Lokan } \\
(\mathbf{g r})\end{array}$ & \\
\hline 0 & 400 & $19,77^{\mathrm{f}}$ \\
50 & 350 & $19,23^{\mathrm{e}}$ \\
100 & 300 & $19,10^{\mathrm{d}}$ \\
150 & 250 & $18,60^{\mathrm{c}}$ \\
200 & 200 & $17,49^{\mathrm{b}}$ \\
250 & 150 & $17,27^{\mathrm{a}}$ \\
\hline
\end{tabular}

Ket :Angka yang diikuti oleh kode huruf yang berbeda menunjukkan adanya perbedaan yang nyata pada taraf signifikansi 5\%, (pada kolom yang sama)

Hasil penelitian menunjukkan bahwa perlakuan komposisi daging lokan dan tebu telur berpengaruh nyata terhadap kadar protein abon lokan substitusi tebu telur, pada taraf signifikan 5\%. Semakin banyak daging lokan yang digunakan, kadar protein abon lokan akan semakin meningkat. Kadar protein abon lokan substituri tebu telur berkisar antara 17,27 $\%$ hingga $19,77 \%$, yang artinya kurang lebih $10 \%$ lebih tinggi dibandingkan kadar protein bahan baku lokan, yaitu $5,67-7,37 \%$. Hal ini disebabkan karena terjadinya penurunan kadar air yang cukup signifikan selama proses pengolahan. Abon merupakan makanan olahan kering, dengan kadar air maksimal $7 \%$, sedangkan lokan memiliki kadar air sebesar $87 \%$. Pengurangan air selama pengolahan abin lokan, secara otomatis akan meningkatkan kadar komponen lain, termasuk protein.

Penetapan kadar protein perlu dilakukan untuk mengetahui kondisi bahan pangan makanan yang dibandingkan dengan kondisi standar. Hasil penelitian yang telah dilakukan, menunjukkan bahwa abon lokan substitusi tebu telur mempunyai kadar prootein yang sesuai standar, SNI No. 01-3820-2005, yang menyatakan bahwa syarat minimal kadar protein pada produk abon adalah minimal $15,0 \%$.

\section{Kadar Serat Kasar Abon Lokan Substitusi Tebu Telur}

Serat kasar adalah residu organik dari karbohidrat yang dipisahkan melalui ekstraksi eter dengan menggunakan larutan asam dan basa. Serat kasar terdiri dari selulose dan hemiselulose yang berfungsi sebagai bahan pelindung tumbuh-tumbuhan. Kandungan serat kasar yang terlalu tinggi akan mengganggu proses pencernaan dan penyerapan sari makanan (Mudjiman, 2008). Hasil analisis serat kasar abon lokan substitusi tebu telur disajikan pada tabel 2. 
Tabel 2. Kadar Serat Kasar Abon Lokan Substitusi Tebu Telur (\%)

\begin{tabular}{ccc}
\hline \multicolumn{2}{c}{ Perlakuan Komposisi } & Rerata \\
\cline { 1 - 2 } $\begin{array}{c}\text { Tebu Telur } \\
(\text { gr) }\end{array}$ & $\begin{array}{c}\text { Daging Lokan } \\
(\text { gr) }\end{array}$ & $(\%)$ \\
\hline 0 & 400 & $0,23^{\mathrm{a}}$ \\
50 & 350 & $0,33^{\mathrm{b}}$ \\
100 & 300 & $0,56^{\mathrm{c}}$ \\
150 & 250 & $0,96^{\mathrm{d}}$ \\
200 & 200 & $1,14^{\mathrm{e}}$ \\
250 & 150 & $1,29^{\mathrm{f}}$ \\
\hline
\end{tabular}

Ket :Angka yang diikuti oleh kode huruf yang berbeda menunjukkan adanya perbedaan yang nyata pada taraf signifikansi 5\%, (pada kolom yang sama)

Hasil penelitian menunjukkan bahwa terdapat perbedaan yang nyata pada semua perlakuan terhadap kadar serat kasar abon lokan substitusi tebu telur dengan taraf signifikan 5\%. Semakin tinggi komposisi tebu telur, maka kadar serat kasar abon yang dihasilkan akan semakin tinggi pula. Hal ini disebabkan karena tebu telur yang mempunyai kadar serat yang terkandung dalam karbohidrat yang jauh lebih tinggi, yaitu 7,6\%, dibandingkan kadar karbohidrat dalam lokan yang hanya 3,3\%. Menurut Sitorus (2009), sayuran yang melalui proses pemasakan jumlah seratnya akan meningkat. Pada proses pengolahan produk pangan akan menghilangkan beberapa zat gizi sehingga berat sayuran menjadi lebih kecil dari berat keringnya. Proses pemasakan juga menyebabkan terjadinya proses pencoklatan yang dalam analisis gizi terhitung sebagai serat pada makanan. Kemudian Daulay, (2013) menambahkan bahwa tebu telur memiliki dan kaya serat kasar 0,7\%, mengandung air 89 gr, karbohidrat 3\%, lemak 0,4\%, $\mathrm{Ca} 40 \mathrm{mg}$, Fe 0.4-2 mg, fosfor $80 \mathrm{mg}$, vitamin C $21 \mathrm{mg}$ dengan total energi sebesar 143-160 kJ/100 gr.

Hasil analisis kadar serat kasar abon lokan substitusi tebu telur berkisar antara $0,237 \%$ hingga $1,297 \%$. Jika dibandingkan dengan standar SNI abon No. 01-3820-2005, yang menyatakan bahwa kadar serat kasar produk abon maksimal adalah 1,04\%, maka perlakuan komposisi tebu telur : lokan $150: 250$ gram, adalah komposisi tertinggi untuk tebu telur sebagai substituen, dengan kadar serat kasar sebesar 0,96\%. Penambahan komposisi tebu telur akan meningkatkan kadar serat kasar abon, sehingga melampaui kadar serat kasar yang disyaratkan oleh SNI, walaupun perbedaannya tidak terlalu tinggi. Tingginya kadar serat kasar dalam abon lokan substitusi tebu telur memberikan peluang alternatif produk pangan bagi 
konsumen yang menghendaki makanan berserat tinggi.

\section{Uji Organoleptik Warna Abon Lokan}

\section{Substitusi Tebu Telur}

Warna merupakan komponen yang sangat penting dalam menentukan kualitas atau derajat penerimaan dari suatu bahan pangan. Sari (2008) menyatakan bahwa warna yang menarik akan meningkatkan derajat penerimaan atau nilai suatu bahan pangan dan menunjukkan kandungan zat di dalam pangan tersebut. Warna sangat mempengaruhi tingkat penerimaan konsumen, walaupun kurang berhubungan dengan gizi, rasa atau nilai fungsional lainnya (Setyaningsih, dkk., 2010). Hasil rerata uji organoleptik warna abon lokan substitusi tebu telur disajikan pada Tabel 3.

Hasil analisis tingkat kesukaan panelis terhadap warna abon lokan substitusi tebu telur, menunjukkan bahwa semakin banyak tebu telur yang ditambahkan, tingkat kesukaan panelis semakin tinggi. Berdasarkan pengamatan yang dilakukan peneliti, semakin banyak tebu telur yang ditambahkan, abon lokan yang dihasilkan memiliki warna yang semakin cerah. Hal senada diungkapkan oleh Chaniago R (2017) dan Sigit dkk (2017) yang menyatakan bahwa secara umum panelis menyukai abon dengan warna kuning kecoklatan. Warna abon lokan untuk seluruh pengamatan terdeteksi dari coklat kehitaman hingga kuning kecoklatan. Hal ini diduga karena reaksi maillard yang terjadi selama pemasakan. Asam amino dan laktosa dalam daging lokan mengalami serangkaian reaksi selama pemasakan sehingga membentuk senyawa volatil dan senyawa polimer yang berwarna coklat. Begitu pula kandungan lemak dalam daging lokan yang akan teroksidasi membentuk senyawa radikal yang kemudian berkondensasi satu sama lain membentuk senyawa berwarna coklat. (Agustini dkk, 2015). Semakin banyak sumber protein dalam bahan maka semakin potensi terjadinya reaksi maillard juga semakin tinggi. Dalam penelitian ini, digunakan bahan baku lokan yang memiliki kadar protein lebih tinggi dibandingkan tebu telur, sehingga semakin banyak lokan yang ditambahkan, produk abon yang dihasilkan memiliki warna yang semakin gelap. Hal ini senada dengan hasil analisis kadar protein pada produk abon lokan substitusi yang telah dilakukan, yaitu semakin banyak lokan yang digunakan, maka kadar protein abon lokan akan semakin tinggi. 
Tabel 3. Hasil Rerata Uji Organoleptik Warna Abon Lokan Substitusi Tebu Telur

\begin{tabular}{ccc}
\hline \multicolumn{2}{c}{ Perlakuan Komposisi } & Rerata \\
\cline { 1 - 2 } $\begin{array}{c}\text { Tebu Telur } \\
(\text { gr })\end{array}$ & $\begin{array}{c}\text { Daging Lokan } \\
(\mathbf{g r})\end{array}$ & \\
\hline 0 & 400 & $2,40^{\mathrm{d}}$ \\
50 & 350 & $2,85^{\mathrm{cd}}$ \\
100 & 300 & $3,65^{\mathrm{bc}}$ \\
150 & 250 & $3,80^{\mathrm{b}}$ \\
200 & 200 & $4,55^{\mathrm{ab}}$ \\
250 & 150 & $4,85^{\mathrm{a}}$ \\
\hline
\end{tabular}

Angka yang diikuti oleh kode huruf yang berbeda menunjukkan adanya perbedaan yang nyata pada taraf signifikansi $5 \%$, (pada kolom yang sama)

Skala $(1=$ sangat tidak suka, $2=$ tidak suka, $3=$ agak suka, $4=$ suka, $5=$ sangat suka $)$.

\section{Uji Organoleptik Rasa Abon Lokan}

\section{Substitusi Tebu Telur}

Rasa merupakan faktor yang paling penting dalam menentukan keputusan bagi konsumen untuk menerima atau menolak suatu makanan ataupun produk pangan (Soekarto, 2005). Rasa dipengaruhi oleh senyawa kimia, suhu, konsentrasi dan interaksi dengan komponen rasa yang lain. Rasa diasumsikan menjadi empat rasa dasar, yaitu manis, asam, pahit dan asin
(Winarno, 2008). Rasa merupakan faktor penentu daya terima konsumen terhadap produk pangan.Faktor rasa memegang peranan penting dalam pemilihan produk oleh konsumen.Rasa merupakan respon lidah terhadap rangsangan yang diberikan oleh suatu makanan. Konsumen akan memutuskan menerima atau menolak produk dengan empat rasa tersebut. Hasil rerata uji organoleptik abon lokan dengan substitusi tebu telur disajikan pada Tabel 4.

Tabel 4. Hasil Rerata Uji Organoleptik Rasa Abon Lokan Substitusi Tebu Telur

\begin{tabular}{ccc}
\hline \multicolumn{2}{c}{ Perlakuan Komposisi } & Rerata \\
\cline { 1 - 2 } $\begin{array}{c}\text { Tebu Telur } \\
(\text { gr })\end{array}$ & $\begin{array}{c}\text { Daging Lokan } \\
(\text { gr) }\end{array}$ & \\
\hline 0 & 400 & $2,85^{\mathrm{de}}$ \\
50 & 350 & $3,10^{\mathrm{cd}}$ \\
100 & 300 & $3,75^{\mathrm{bc}}$ \\
150 & 250 & $4,80^{\mathrm{a}}$ \\
200 & 200 & $4,25^{\mathrm{ab}}$ \\
250 & 150 & $2,25^{\mathrm{e}}$ \\
\hline
\end{tabular}

Angka yang diikuti oleh kode huruf yang berbeda menunjukkan adanya perbedaan yang nyata pada taraf signifikansi $5 \%$, (pada kolom yang sama)

Skala $(1=$ sangat tidak suka, $2=$ tidak suka, $3=$ agak suka, $4=$ suka, $5=$ sangat suka $)$. 
Rasa merupakan gabungan dari berbagai bahan dan bumbu yang telah melalui beberapa proses pengolahan. Ketepatan dalam pemberian bumbu dan pengolahan makanan akan mempengaruhi rasa dari makanan yang dihasilkan. Rasa adalah faktor yang cukup penting dari suatu produk makanan, penilaian cita rasa menunjukkanpenerimaan konsumen terhadap suatu bahan makanan, yang umumnya dilakukan dengan penilaian dengan indera manusia. (Winarno, 2008)

Hasil uji sensoris abon lokan substitusi tebu telur menunjukkan bahwa semakin tinggi komposisi tebu telur, tingkat kesukaan panelis terhadap abon lokan semakin tinggi, kecuali pada perlakuan komposisi tebu telur : lokan $250: 150$ gram. Tingkat kesukaan panelis terhadap rasa abon lokan tertinggi adalah pada perlakuan (150 gr tebu telur dan 250 gr daging lokan) yaitu sebesar 4.80 dengan kategori sangat suka, rasa yang terbentuk dari perlakuan ini adalah khas tebu telur. Hal ini diduga karena penambahan tebu telur yang tidak terlalu banyak dengan jumlah daging lokan agak lebih banyak dari tebu telur pada pembuatan abon lokan, sehingga rasa yang dihasilkan adalah rasa khas dari tebu telur yang ringan. Fachrudin, (2007) menyatakan bahwa rasa yang terbentuk pada produk pangan selain diperoleh dari penambahan daging juga diduga disebabkan oleh penggunaan bahan pangan lain. Penggunaan tebu telur dalam proses pembuatan abon membantu memperkaya rasa sehingga akan memperbaiki rasa abon. Menurut Setyaningsih, dkk. (2010), menyatakan bahwa rasa suatu bahan makanan merupakan hasil kerjasama indera-indera lain, seperti indera penglihatan, pembauan, pendengaran, dan perabaan. Substitusi tebu telur lebih mempengaruhi rasa sehingga menyebabkan adanya pengaruh berbeda nyata pada cita rasa produk pangan (Puspita dkk, 2016).

\section{Uji Organoleptik Tekstur Abon Lokan Substitusi Tebu Telur}

Tekstur merupakan sensasi tekanan yang dapat diamati dengan mulut (pada waktu digigit, dikunyah, ditelan) ataupun dengan perabaan dengan jari. Tekstur pada produk makanan dan minuman akan mempengaruhi penilaian tentang diterima atau tidaknya produk tersebut. Tekstur dan konsentrasi bahan akan mempengaruhi cita rasa bahan (Yuliana, 2013). Hasil rerata uji organoleptik abon lokan substitusi tebu telur disajikan pada Tabel 5. 
Tabel 5. Hasil Rerata Uji Organoleptik Tekstur Abon Lokan Substitusi Tebu Telur

\begin{tabular}{|c|c|c|}
\hline \multicolumn{2}{|c|}{ Perlakuan Komposisi } & \multirow{2}{*}{$\begin{array}{c}\text { Rerata } \\
(\%)\end{array}$} \\
\hline $\begin{array}{c}\text { Tebu Telur } \\
\text { (gr) }\end{array}$ & $\begin{array}{c}\text { Daging Lokan } \\
\text { (gr) }\end{array}$ & \\
\hline 0 & 400 & $3,30^{b c}$ \\
\hline 50 & 350 & $3,70^{\mathrm{b}}$ \\
\hline 100 & 300 & $4,55^{b c}$ \\
\hline 150 & 250 & $4,70^{\mathrm{a}}$ \\
\hline 200 & 200 & $2,45^{\mathrm{cd}}$ \\
\hline 250 & 150 & $2,30^{\mathrm{d}}$ \\
\hline
\end{tabular}

Angka yang diikuti oleh kode huruf yang berbeda menunjukkan adanya perbedaan yang nyata pada taraf signifikansi $5 \%$, (pada kolom yang sama)

Skala $(1=$ sangat tidak suka, $2=$ tidak suka, $3=$ agak suka, $4=$ suka, $5=$ sangat suka $)$.

Berdasarkan tabel 5, hasil penilaian rasa abon lokan substitusi tebu telur terdapat perbedaan yang nyata pada taraf signifikan 5\%.pada semua sampel, dengan taraf signifikan 5\%. Hal ini menunjukkan bahwa ada pengaruh dari keenam perlakuan penambahan perlakuan tebu telur dan daging lokan. Dimana rerata penilaian tekstur paling tinggi dengan skor 4,70 dengan skala sangat suka pada perlakuan (150 gr tebu telur dan 250 gr daging lokan). Hal ini diduga penambahan tebu telur yang tidak terlalu banyak dengan jumlah daging lokan agak lebih banyak dari tebu telur pada pembuatan abon lokan, tekstur yang dihasilkan makin disukai oleh panelis. Hal ini disebabkan karena teksturnya tidak terlalu kasar dan tidak terlalu halus. Chaniago (2015) menyatakan bahwa konsentrasi tebu telur juga mempengaruhi tekstur, semakin banyak jumlah konsentrasi tebu telur pada pengolahan pangan maka tekstur yang dihasilkan akan semakin kasar. Kemudian Herawati (2008), menyatakan bahwa tekstur yang lembek akan kurang disukai oleh konsumen sebaliknya tekstur yang terlalu keras juga kurang disukai konsumen, untuk itu perlu diperhatikan komposisis bahan sehingga merupakan karakteristik yang diharapkan oleh konsumen.

$$
\text { Kemudian Soeparno }
$$
berpendapat bahwa tekstur abon dipengaruhi oleh jenis daging dan pemasakan daging. Pemasakan daging akan mempengaruhi tingkat suiran daging yang berhubungan erat dengan tekstur abon.Jenis daging yang digunakan harus memiliki sedikit tendon, sebab akan berpengaruh pada meratanya tingkat suiran. Kemudian perebusan akan menghasilkan tekstur daging lebih empuk daripada yang dikukus dalam hal tingkat keempukan daging masak. Pengukusan mengakibatkan tekstur yang kompak atau padat, sehingga mempengaruhi penyuiran daging menjadi lebih teratur.Pemasakan 
dapat meningkatkan atau menurunkan keempukan daging. Lama waktu pemasakan mempengaruhi pelunakan kolagen, sedangkan suhu pemasakan lebih mempengaruhi kealotan miofibrilar.

\section{Penentuan Komposisi Bahan yang} Tepat dalam Pengolahan Abon Lokan

Hasil penelitian menunjukkan bahwa perlakuan terbaik pada pengolahan abon lokan substitusi tebu telur adalah dengan perlakuan komposisi 150 gram tebu telur dan 250 lokan, dengan karakteristik kimia dan organoleptik abon lokan berdasarkan kadar protein, kadar serat kasar, dan uji organoleptik (warna, rasa, dan tekstur) seperti pada Tabel 6 .

Berdasarkan Tabel 6 diketahui bahwa konsentrasi abon lokan substitusi tebu telur yang tepat berdasarkan kadar protein adalah pada perlakuan (150 gr tebu telur dan 250 gr daging lokan) yaitu sebesar $18,60 \%$, sesuai syarat mutu abon berdasarkan SNI 01-3820-2005, yang menyatakan kadar protein abon minimal sebesar $15,0 \%$. Hasil penelitian menunjukkan bahwa substitusi bahan lain (tebu telur) dalam pengolahan abon akan memberikan pengaruh positif terhadap kualitas sensoris abon lokan. Hal ini senada dengan hasil penelitian Ismail dkk (2017), yang menyatakan bahwa substitusi jantung pisang sebesar 30\%, memiliki tingkat kesukaan panelis yang lebih baik dari pada abon tanpa penambahan jantung pisang.

Konsentrasi abon lokan substitusi tebu telur yang tepat berdasarkan kadar serat kasar abon terdapat pada perlakuan (150 gr tebu telur dan 250 gr daging lokan) yaitu sebesar $0,96 \%$ sesuai syarat mutu abon berdasarkan SNI 01-38202005, yang menyatakan syarat kadar serat kasar abon adalah maksimal 1,04\%.

\section{Tabel 6. Karakteristik Kimia dan Organoleptik Abon Lokan Substitusi Tebu Telur}

\begin{tabular}{|c|c|c|c|}
\hline \multirow[b]{2}{*}{ Komponen } & \multicolumn{2}{|c|}{ Perlakuan Komposisi } & \multirow[b]{2}{*}{ Nilai } \\
\hline & $\begin{array}{c}\text { Tebu Telur } \\
\text { (gr) }\end{array}$ & $\begin{array}{c}\text { Daging Lokan } \\
\text { (gr) }\end{array}$ & \\
\hline Kadar Protein & 150 & 250 & $18,60 \%$ \\
\hline Kadar Serat Kasar & 150 & 250 & $0,96 \%$ \\
\hline Organoleptik Warna & 150 & 250 & 3,80 \\
\hline Organoleptik Rasa & 150 & 250 & 4,80 \\
\hline Organoleptik Tekstur & 150 & 250 & 4,70 \\
\hline
\end{tabular}

Angka yang diikuti oleh kode huruf yang berbeda menunjukkan adanya perbedaan yang nyata pada taraf signifikansi 5\%, (pada kolom yang sama)

Skala $(1=$ sangat tidak suka, $2=$ tidak suka, $3=$ agak suka, $4=$ suka, $5=$ sangat suka $)$. 
Konsentrasi abon lokan substitusi tebu telur yang tepat untuk warna abon adalah perlakuan (150 gr tebu telur dan 250 gr daging lokan) yaitu sebesar 3,80 dengan kategori sangat suka, warna yang terbentuk dari perlakuan ini adalah perpaduan coklat dengan lebih banyak kekuningan. Hal ini disebabkan panelis menyukai abon lokan dengan warna yang agak kekuningan. Semakin tinggi kadar tebu telur semakin kuning warna yang dihasilkan sehingga substitusi tebu telur meningkatkan kesukaan panelis karena warna yang dihasilkan agak kekuningan yang berasal dari warna tebu telur.

Konsentrasi abon lokan substitusi tebu telur yang tepat untuk rasa abon adalah perlakuan (150 gr tebu telur dan 250 gr daging lokan) yaitu sebesar 4.80 dengan kategori sangat suka, rasa yang terbentuk dari perlakuan ini adalah khas tebu telur. Hal ini diduga penambahan tebu telur yang tidak terlalu banyak dengan jumlah daging lokan agak lebih banyak dari tebu telur pada pembuatan abon lokan, rasa yang dihasilkan makin disukai oleh panelis.

Konsentrasi abon lokan substitusi tebu telur yang tepat untuk tekstur abon adalah perlakuan (150 gr tebu telur dan 250 gr daging lokan) dengan skor 4,70 dengan skala sangat suka. Hal ini diduga penambahan tebu telur yang tidak terlalu banyak dengan jumlah daging lokan agak lebih banyak dari tebu telur pada pembuatan abon lokan, tekstur yang dihasilkan makin disukai oleh panelis.Hal ini disebabkan karena teksturnya tidak terlalu kasar dan tidak terlalu halus.

\section{Analisis Usaha Abon Lokan}

Analisis usaha atau disebut juga feasibility study adalah kegiatan untuk menilai sejauh mana manfaat yang dapat diperoleh dalam melaksanakan suatu kegiatan usaha. Hasil analisis ini digunakan sebagai bahan pertimbangan dalam mengambil keputusan, apakah menerima atau menolak dari suatu gagasan usaha. Tujuan analisis usaha adalah untuk mengetahui posisi keuangan perusahaan dalam satu periode tertentu, baik harta, kewajiban, modal maupun hasil usaha yang telah dicapai untuk beberapa periode, untuk mengetahui kelemahan-kelemahan apa saja yang menjadi kekeurangan perusahaan, Untuk mengetahui kekuatan-kekuatan yang dimiliki, untuk mengetahui langkahlangkah perbaikan apa saja yang perlu dilakukan ke depan yang berkaitan dengan posisi keuangan perusahaan saat ini) untuk melakukan penilaian kinerja manajemen ke depan apakah perlu penyegaran atau tidak karena sudah dianggap berhasil atau gagal, dapat juga digunakan sebagai pembanding dengan 
perusahaan sejenis tentang hasil yang mereka capai.

Untuk membuat abon lokan substitusi tebu telur dengan formulasi tebu telur $150 \mathrm{gr}$ : $250 \mathrm{gr}$ daging lokan, diperlukan bahan baku seperti minyak goreng, bawang merah, bawang putih, garam, lengkuas, serai, ketumbar, kunyit, lada, santan. Untuk melihat total biaya bahan baku pembuatan abon lokan substitusi tebu telur dengan formulasi tebu telur 150 gr : 250 gr dapat dilihat pada Tabel 7.

Selanjutnya untuk membuat abon lokan substitusi tebu telur dengan formulasi tebu telur $150 \mathrm{gr}$ : $250 \mathrm{gr}$ daging lokan, diperlukan alat untuk pengolahan abon lokan substitusi tebu telur yaitu : baskom, wajan, kompor, sendok, blender, pengepres, garpu, kompor gas. Untuk melihat total biaya penyusutan alat yang digunakan dalam pembuatan abon lokan substitusi tebu telur dengan formulasi tebu telur 150 gr : 250 gr dapat dilihat pada Tabel 8.

Kemudian biaya lainnya untuk membuat abon lokan substitusi tebu telur dengan formulasi tebu telur $150 \mathrm{gr}: 250$ gr daging lokan, yaitu : biaya pengemasan dan biaya tenaga kerja. Untuk melihat total biaya pengemasan dan tenaga kerja dalam pembuatan abon lokan substitusi tebu telur dengan formulasi tebu telur 150 gr : 250 gr dapat dilihat pada Tabel 9.

Tabel 7. Biaya Bahan Baku Abon Lokan Substitusi Tebu Telur dengan Formulasi tebu telur $150 \mathrm{gr}$ : $250 \mathrm{gr}$ daging lokan

\begin{tabular}{lll}
\hline No & \multicolumn{1}{c}{ Bahan } & \multicolumn{1}{c}{ Harga } \\
\hline 1 & Daging lokan 250 gr & Rp. 10.000 \\
2 & Tebu telur 150 gr & Rp. 3.000 \\
3 & Minyak goreng 200 gr & Rp. 2.200 \\
4 & Bawang Merah 19,5 gr & Rp. 780 \\
5 & Bawang Putih 10 gr & Rp. 600 \\
6 & Santan 150 ml & Rp. 1200 \\
7 & Garam 2,5 gr & Rp. 70 \\
8 & Lengkuas 30 gr & Rp. 90 \\
9 & Serai 20 gr & Rp. 70 \\
10 & Ketumbar 0,9 gr & Rp. 14 \\
11 & Kunyit 1,5 gr & Rp. 50 \\
12 & Lada 1,7 gr & Rp. 90 \\
13 & Bahan bakar Lpj / & Rp. 2.000 \\
\hline & Total biaya & Rp. 20.164
\end{tabular}

Sumber: Data primer (2019) 
Tabel 8. Biaya Penyusutan Alat dalam Pembuatan Abon Lokan Substitusi Tebu Telur dengan Formulasi tebu telur $150 \mathrm{gr}: 250 \mathrm{gr}$ daging lokan

\begin{tabular}{lrrrrrr}
\hline Nama Alat & $\begin{array}{c}\text { Harga } \\
\text { awal } \\
\text { (Rp) }\end{array}$ & $\begin{array}{c}\text { Harga } \\
\text { Sisa (Rp) }\end{array}$ & $\begin{array}{c}\text { Umur } \\
\text { Ekonom } \\
\text { is/th }\end{array}$ & $\begin{array}{c}\text { Umur } \\
\text { Ekonomis/ } \\
\text { bulan }\end{array}$ & $\begin{array}{c}\text { Harga } \\
\text { akhir } \\
\text { (Rp) }\end{array}$ & $\begin{array}{c}\text { Penyu- } \\
\text { sutan }\end{array}$ \\
\hline Baskom & 10.000 & 5.000 & 7 & 84 & 5.000 & 60 \\
Wajan & 28.000 & 1.250 & 10 & 120 & 26.750 & 223 \\
Kompor & 200.000 & 100.000 & 7 & 84 & 100.000 & 1.190 \\
Sendok & 800 & 400 & 10 & 120 & 400 & 3 \\
Blender & 435.000 & 250.000 & 3 & 36 & 185.000 & 5.139 \\
Pengepres & 167.000 & 90.000 & 8 & 96 & 77.000 & 802 \\
Garpu & 1.500 & 800 & 10 & 120 & 700 & 6 \\
Pisau & 11.000 & 6.000 & 7 & 84 & 5.000 & 60 \\
\hline \multicolumn{7}{c}{ Jumlah } \\
\hline
\end{tabular}

Sumber: Data primer (2019)

Tabel 9. Biaya lainnya dalam pembuatan Abon Lokan Substitusi Tebu Telur dengan Formulasi tebu telur 150 gr : 250 gr daging lokan

\begin{tabular}{llc}
\hline No & \multicolumn{1}{c}{ Jenis Biaya } & Harga $(\mathbf{R p})$ \\
\hline 1 & Kemasan & 1.000 \\
2 & Tenaga kerja & 5.000 \\
\hline Jumlah & $\mathbf{6 . 0 0 0}$ \\
\hline
\end{tabular}

Sumber: Data primer (2019)

Selanjutnya untuk memudahkan penghitungan biaya yang telah kita peroleh dalam membuat abon lokan substitusi tebu telur dengan formulasi tebu telur 150 gr : 250 gr daging lokan, maka semua biaya kita kelompokkan menjadi satu yang disebut total biaya. Untuk menentukan total biaya keseluruhan dalam pembuatan abon lokan substitusi tebu telur dengan formulasi tebu telur 150 gr : 250 gr dapat dilihat pada tabel 10.
Untuk mengetahui berapa keuntungan yang diperoleh, maka kita harus mengetahui berapa total penerimaan dengan melihat data produksi dan harga abon lokan substitusi tebu telur dengan formulasi tebu telur $150 \mathrm{gr}$ : $250 \mathrm{gr}$ daging lokan. Untuk melihat keuntungan abon lokan substitusi tebu telur dengan formulasi tebu telur $150 \mathrm{gr}$ : $250 \mathrm{gr}$ dapat disajikan pada Tabel 11. 
Tabel 10.Total Biaya pembuatan Abon Lokan Substitusi Tebu Telur dengan Formulasi tebu telur $150 \mathrm{gr}$ : 250 gr daging lokan

\begin{tabular}{llc}
\hline No & \multicolumn{1}{c}{ Jenis Biaya } & Harga $(\mathbf{R p )}$ \\
\hline 1 & Bahan baku & 20.164 \\
2 & Penyusutan alat & 7.483 \\
3 & Biaya lainnya & 6.000 \\
\hline Total Biaya & $\mathbf{3 3 . 6 4 7}$ \\
\hline
\end{tabular}

Sumber: Data primer (2019)

Tabel 11.Penerimaan dari usaha pembuatan Abon Lokan Substitusi Tebu Telur dengan Formulasi tebu telur 150 gr : 250 gr daging lokan

\begin{tabular}{lccc}
\hline No & Produksi & Harga & Penerimaan \\
\hline 1 & $360 g r$ & Rp. 200/gr & Rp. 72.000
\end{tabular}

Sumber: Data primer (2019)

Ket : Harga abon $=$ Rp. $200.000 / \mathrm{kg}$

Untuk mengetahui berapa besar keuntungan dengan menggunakan rumus keuntungan yaitu diperoleh dengan cara mengurangkan total penerimaan dengan total biaya :

$$
\mathbf{I}=\mathbf{T R} \text { - }
$$

\section{TC}

Keterangan

$$
\begin{aligned}
& \mathrm{I}=\text { Keuntungan } \\
& \mathrm{TR}=\text { Total Penerimaan (Total }
\end{aligned}
$$
Revenue)

$\mathrm{TC}=$ Total Biaya $($ Total Cost $)$

$$
\begin{aligned}
\mathbf{I} & =\mathbf{T R}-\mathbf{T C} \\
& =72.000-33.647 \\
& =38.353
\end{aligned}
$$

Jadi pembuatan abon lokan substitusi tebu telur dengan formulasi tebu telur $150 \mathrm{gr}: 250 \mathrm{gr}$ diperoleh keuntungan sebesar Rp 38.353.

\section{KESIMPULAN DAN SARAN}

\section{Kesimpulan}

Hasil penelitian menunjukkan bahwa perlakuan komposisi daging lokan dan tebu telur berpengaruh nyata terhadap kadar protein dan kadar serat kasar abon lokan substitusi tebu telur, Semakin banyak daging lokan yang digunakan, kadar protein abon lokan akan semakin meningkat, sedangkan kadar serat kasar semakin menurun. Kadar protein abon lokan substitusi tebu telur berkisar antara 17,27 \% hingga 19,77\% dan kadar serat kasar berkisar antara 0,23 - 1,29\%. Berdasarkan karakteristik kimia dan sensorisnya, komposisi terbaik untuk pengolahan abon lokan substitusi tebu telur adalah 150 gram tebu telur dan 250 gram lokan, dengan nilai keuntungan usaha sebesar Rp. 38.353 untuk satu kali produksi. 


\section{Saran}

Perlu dilakukan penelitian lebih lanjut terkait metode penyuwiran daging lokan yang efektif, untuk mempernudah proses pengolahan dan mempersingkat waktu pengolahan.

\section{DAFTAR PUSTAKA}

Agustini, S. Priyanto, G. Hamzah, B. Santoso, B dan Pambayun, R. 2015. Pengaruh Modifikasi Proses terhadap Kualitas Sensoris Kue Delapan Jam. Jurnal Dinamika Penelitian Industri. 26 (II) : 107-115. Palembang.

Astawan, M. 2008. Teknologi Pengolahan Pangan Hewani Tepat Guna. Akademi Presindo. Jakarta.

Badan Standarisasi Nasional. 2005. Abon. BSN. Jakarta.

Chaniago.2015. Potensi Biomassa Terubuk (Saccharum edule Hasskarl) sebagai Pakan Untuk Pertambahan Bobot Badan Sapi. Skripsi. Universitas Muhammadiyah Luwuk. Sulawesi Tengah.

Chaniago R. 2016. Pengaruh Formulasi Daging Buah Pisang Lowe (Musa acuminata L.) dan Daging Ayam Terhadap Karakteristik Sensoris Nugget. Jurnal Teknologi Pertanian Universitas Mulawarman. 12(1):16-20. Samarinda.

Daulay. 2013. Mempelajari Peningkatan Daya Simpan dan Pemanfaatan Tebu Terubuk (Saccharum edule Hassk). Jurusan Teknologi Pangan dan Gizi, Fakultas Teknologi Pertanian.Institut Pertanian. Bogor.

Fachruddin. 2007. Membuat Aneka Abon. Penerbit Kanisius.Yogyakarta.
Herawati, H. 2008. Penentuan Umur Simpan Produk Pangan. Jurnal Litbang Pertanian, 27(4).

Ismail, A.M dan Putra, D.E. 2017. Inovasi Pembuatan Abon Ikan Cakalang dengan Penambahan Jantung Pisang. Jurnal Agritech. XIX (I) : 45-54. Fakultas Teknologi Pertanian Universitas Gadjah Mada. Yogyakarta.

Leksono, T dan Syahrul. 2001. Studi Mutu dan Penerimaan Konsumen terhadap Abon Ikan. Jurnal Natur Indonesia III (2) : $178-184$.

Mudjiman, A. 2008. Makanan Ikan. Penebar Swadaya. Jakarta.

Puspita. 2016. Teknologi Pengolahan Pangan. Akademi Presindo. Jakarta.

Sari dan Wulan, R. 2008. Dengerous Junk Food. Penerbit O2. Yogyakarta.

Setyaningsih, D. Apriyantono, A dan Sari, M.P. 2010. Analisis Sensori untuk Industri Pangan dan Agro. IPB Press. Bogor.

Sigit, M. Akbar, M dan Fianti, L. 2017. Kualitas Organoleptik Abon Ayam yang Diberi Perlakuan Substitusi Kacang Tanah (Arachis hypogaea L.). Jurnal Filia Cendekia. II (1) : 1-8. http://ejournal.fp.uniskakediri.ac.id. Fakultas Pertanian Uniska. Kediri

Sitorus, M. 2009. Spektroskopi (Elusidasi Struktur Molekul Organik). Graha Ilmu. Yogyakarta.

Soeparno. 2008. Ilmu dan Teknologi Daging Cetakan Keempat. Gadjah Mada University Press, Yogyakarta.

Sudarmadji S, dkk. 1997. Prosedur Analisa untuk Bahan Makanan dan Pertanian. Liberty. Yogyakarta.

Suryani et al,.2005. Membuat Aneka Abon. Penebar Swadaya. Jakarta.

Sutrisno. 2010. Produk dan Bahan Pangan. Kanisius. Jakarta. 
Suwignyo.2008. Studi Beberapa Aspek Biologi Lokan di Teluk Jakarta. Fakultas Perikanan Institut Pertanian Bogor.

Syarief dan Anies. 2008. Pengetahuan Bahan untuk Industri Pertanian. PT Mediyatama Sarana Perkasa. Jakarta.
Winarno.2008. Kimia Pangan dan Gizi. PT. Gramedia Pustaka Utama, Jakarta.

Yuliana, 2013.Ciri-Ciri dan Kerusakan pada Pangan. Trubus Agriwidya, Yogyakarta. 